\title{
SLUSH-FLOW QUESTIONNAIRE
}

\author{
by \\ Lawrence J. Onesti \\ (Department of Geology, Indiana University, Bloomington, IN 47405, U.S.A.) \\ and \\ Erik Hestnes \\ (Norwegian Geotechnical Institute, P.O. Box 40, Taasen, N-0801 Oslo 8, Norway)
}

\section{ABSTRACT}

Questionnaires concerning slush flows were distributed globally. The purpose of the questionnaire was to determine the geographic distribution of slush-flow activity and also to collect information concerning the most commonly used nomenclature, release conditions, the season of occurrence, the type of terrain most susceptible to slush-flow occurrences, the characteristics of starting zones, paths and run-out zones, geomorphic activity, type of damage likely to result, and hazard control.

Individuals having first-hand experience of the slush-flow process have been identified. The answers to the questionnaire established that slush flows definitely occur in lower latitudes as well as in the Arctic, and that the slush-flow hazard has not yet received the emphasis that it deserves. Heavy rainfall may cause slush flows at any time during winter, especially in areas with a marine west-coast type of climate. Stream channels and shallow depressions are the most common locations of starting zones, while slush-flow frequency seems to be closely related to the permeability of the substratum. Slush flows are a significant geomorphic agent, and it is noteworthy that there has been an increasing encroachment into potential slush-flow zones as a consequence of human activity.

\section{INTRODUCTION}

There exists a general impression that slush-flow activity, i.e. the rapid mass movement of water-saturated snow, is confined primarily to Arctic and high sub-Arctic regions. The formation of this impression is due partly to the numerous accounts of the occurrence of slush-flow phenomena in such regions. Slush flows were first cited in modern literature by Washburn and Goldthwait (1958), despite the fact that knowledge of slush-flow activity has a much longer history. Osborn (1852) described slush-flow activity near Barrow's Strait in the Canadian Arctic and slush-flow occurrences have been recorded by the Japanese for over 300 years (personal communication from $\mathrm{S}$. Amma).

Recent work by Hestnes (1985) reported slush-flow activity in southern Norway. The occurrence of these events in lower latitudes encouraged the present authors to conduct a global survey to identify slush-flow occurrences and their characteristics. Questionnaires were sent to 927 universities, research centers, engineering institutes, and individuals in 44 countries (Table I). Most of the addresses were selected from mailing lists obtained from the International Glaciological Society, International Snow Science Workshop Committee, the American Association of Avalanche Professionals, and the publication World of learning.

Although responses to the questionnaire were fewer than had been hoped for, 129 questionnaires were returned. Of these, only 80 have been analyzed, because the
TABLE I. QUESTIONNAIRE DISTRIBUTION AND RESPONSE

\begin{tabular}{|c|c|c|c|}
\hline & Sent & $\begin{array}{c}\text { Response } \\
\text { W/A* }\end{array}$ & $\begin{array}{c}\text { Response } \\
\text { I/A }\end{array}$ \\
\hline Norway & 28 & 3 & \\
\hline Sweden & 14 & 2 & \\
\hline Denmark & 8 & 1 & 1 \\
\hline Finland & 8 & 2 & \\
\hline Iceland & 12 & 1 & \\
\hline Portugal & 4 & & 1 \\
\hline Great Britain & 52 & 6 & 1 \\
\hline West Germany & 46 & 4 & 1 \\
\hline East Germany & 8 & 2 & \\
\hline France & 37 & 3 & \\
\hline Austria & 35 & 7 & 1 \\
\hline USSR & 60 & 2 & 1 \\
\hline Switzerland & 29 & 5 & 2 \\
\hline Czechoslovakia & 8 & 1 & \\
\hline Italy & 26 & 2 & 1 \\
\hline Belgium & 6 & 1 & \\
\hline Spain & 18 & & \\
\hline Holland & 8 & 2 & \\
\hline Romania & 3 & & \\
\hline Bulgaria & 3 & & \\
\hline Yugoslavia & 9 & & \\
\hline Hungary & 5 & & \\
\hline Poland & 15 & 3 & \\
\hline Turkey & 5 & & \\
\hline Greece & 4 & & \\
\hline Liechtenstein & 1 & & \\
\hline U.S. & 323 & 20 & 5 \\
\hline Canada & 55 & 5 & 1 \\
\hline Japan & 36 & 1 & \\
\hline China & 5 & & \\
\hline New Zealand & 24 & 5 & \\
\hline Argentina & 6 & & \\
\hline Columbia & 1 & & \\
\hline Chile & 6 & 2 & 1 \\
\hline Bolivia & 1 & & \\
\hline Ecuador & 2 & & \\
\hline Venezuela & 1 & & \\
\hline Peru & 1 & & \\
\hline Mexico & 1 & & \\
\hline India & 7 & & 1 \\
\hline Pakistan & 1 & & \\
\hline Turkey & 2 & & \\
\hline Iran & 1 & & \\
\hline Kenya & 2 & & \\
\hline & 927 & 80 & 17 \\
\hline
\end{tabular}




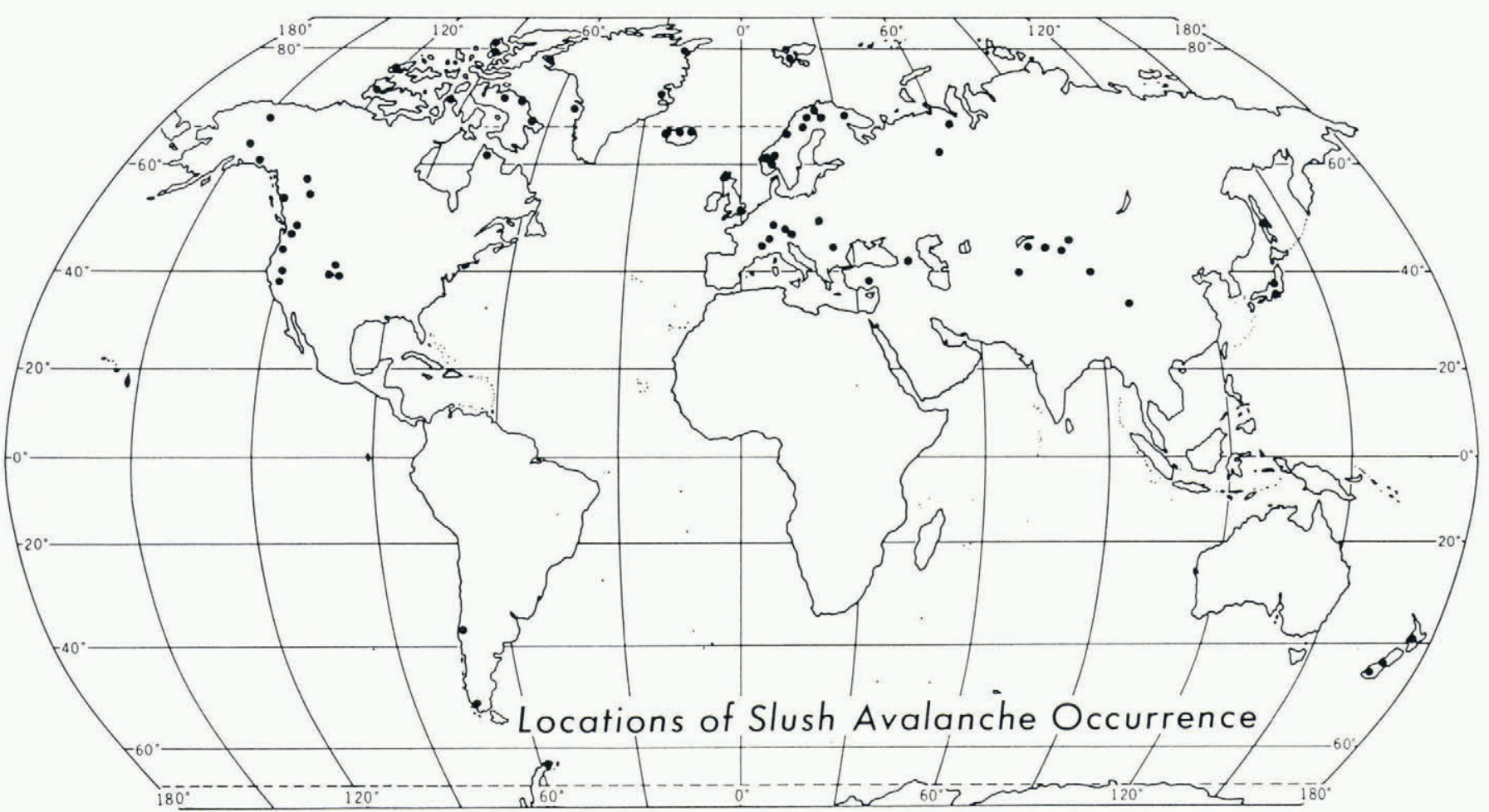

Fig. 1. Locations of slush-avalanche occurrence.

remaining 49 respondents reported that they had little or no knowledge of slush flows. Another 18 replies were not used for reasons such as that they were returned to wrong addresses. Much of the information contributed indicates the existence of both an institutional and a national understanding of slush flows.

Responses to the questionnaire dealing with geographic location indicate that the geographic distribution of slush flows is much broader than would be generally expected. Although the greatest number of occurrences reported are still in the higher latitudes of the sub-polar and polar regions, there are impressive numbers of documented slush flows from the lower latitudes of Europe, Central Asia, China, Japan, and North America, as well as some in the Southern Hemisphere. Locations of the slush-flow occurrences reported in the questionnaires are shown in Figure 1. This information broadens the area of interest and raises many questions concerning those factors which initiate slush-flow occurrence. The initial impression is that higher latitudes present those environments most conducive to slush-flow activity; this conclusion was based solely on the numbers of reported events. However, it now appears that the originally proposed causal factors, of the accelerated rate of snow-pack melting due to intrusion of warm air masses and $24 \mathrm{~h}$ of radiation input (Onesti, 1987), are not the only factors which can induce slush flows. New questions, or more accurately other questions, now enter into the field of slush-flow research.

\section{NOMENCLATURE}

In an attempt to determine which English or international terms have been most commonly used when referring to slush-flow-like phenomena, the following list was provided:

Wet-snow avalanche.

Slush avalanche.

Slush flow.

Mountain torrent.

Wildback.

Other.
Responses were grouped into categories according to the numbers of similar answers as follows:

(1) Slush avalanche

$39 \%$

Slush flows

(2) Wet-snow avalanche

Slush avalanche

Slush flow

(3) Wet-snow avalanche

It was difficult to interpret some of the replies to the questionnaire since it proved problematic for the informants to differentiate between slush flows and wet-snow avalanches. Several questions are raised by the above responses; for example, are there characteristic differences between wet-snow avalanches and slush avalanches or slush flows? If so, what are these differences and how can they be quantified?

In the literature, the terms slush flow and slush avalanche have been used synonymously and the term wetsnow avalanche also sometimes appears, presumably with the same meaning intended. Nyberg (1985) suggested that the term slush avalanche might be restricted to major events, while slush flow could be applied also to small-scale stream break-ups. (In these cases the snow is always saturated.) The term wet-snow avalanche could then better be reserved for avalanches with lower free-water content.

\section{METEOROLOGICAL CONDITIONS RELATED SLUSH-FLOW RELEASE} TO

The questionnaire asked if the process of slush flow was initiated by intense thaw (snow melt), heavy rain, or by other causes. The responses are indicated in Table II.

The high percentage of all slush flows accounted for by intense thaw and/or rainfall could be explained in several ways. Intense melting or heavy rainfall could act as initiating factors if this was seen to imply that slush-flow occurrence could be/is controlled by seasonality of climate. Slush flows caused by intense melting tend to take place in 
TABLE II. METEOROLOGICAL CONDITIONS RELATED TO SLUSH-FLOW RELEASE

Conditions

(1) Thaw or rainfall

(2) Intense thaw (snow melt)

(3) Thaw with rainfall

(4) Heavy rainfall

(5) Others

eariy spring and those due to heavy rainfall take place during the rainy season. The combination of intense melting and heavy rainfall as major causal factors suggests a marine west-coast type of climate where warm-front intrusions and associated rainfall can be experienced at any time during the winter months. $7 \%$ of the total respondents indicated causes other than those mentioned above; they are as follows: (1) flow from springs after break-up, (2) snowfall on warm soil followed by rainfall, and (3) rain combined with other water sources such as a faulty irrigation system. Slush flows are initiated by metamorphosis of the snow-pack under the influence of rapid infusion of free water as the result of intense thawing (accelerated snow melt), heavy rainfall, or both. These conditions appear to be the common denominators that link together the vast majority of slush-flow releases.

\section{SLUSH-FLOW SEASONS}

Until recently, reports in the international literature have associated slush-flow activity with the spring break-up period and accelerated snow melt. Hestnes (1985) and Hestnes and Sandersen (1987) have indicated that slush flows also occur during the winter months when they are associated with the heavy rainfall and above-freezing temperatures experienced during the intrusion of lowpressure systems and associated warm fronts.

Responses to the questionnaire concerning the seasonal occurrence of slush flows showed considerable variation in pattern. Two major seasons of slush-flow activity did emerge, the spring break-up period and the winter season. This was perceived to be the situation for both the Northern and the Southern Hemispheres, although the actual months in which the events occurred varied due to differences both in latitude and in elevation. The climatic environment of a site is also a controlling factor.

$48 \%$ of all respondents indicated that slush flows normally occurred in the spring, being associated with intense snow melt. However, the period identified as spring ranged from March to July. Slush flows which take place in regions of continental climates in the lower mid-latitudes occur as early in the year as March or April. The spring break-up season for slush flows in high-latitude continental climates takes place much later in May, June, or July. Elevation is a significant factor in this timing difference.

$16 \%$ of the response contributors reported that in the Northern Hemisphere slush flows took place during the winter months of December, January, February (or in the corresponding Southern Hemisphere months). In all cases, winter slush flows were associated with areas dominated by a marine west-coast climate.

Slush flows which occur during the summer months account for $18 \%$ of those recorded and reported in response to our questionnaire. These data are difficult to interpret because the summer months ranged from April to October; however, the majority of the respondents indicated events in July and August. In most cases, the geographic location of summer slush-flow occurrences suggests that they are happening in areas of higher elevation, normally on ice caps.

\section{SLUSH-FLOW TERRAIN ASSOCIATION}

Slush flows were reported to occur in a variety of terrain settings, with no particular type of terrain category dominant. Responses to this section of the questionnaire are presented in Table III. Clark and Seppälä (1988) indicated that slush flows also occur in non-alpine areas of the Arctic and sub-Arctic. However, regardless of terrain, slush flows are most likely to occur when appropriate water input to snow-pack and suitable starting-zone conditions are available.

\section{TABLE III. SLUSH-FLOW TERRAIN ASSOCIATION}

(1) Mountainous terrain

(2) Glaciers

(3) Forested hillsides/valley sides

(4) Rural districts

(5) Cultivated land

(6) Urban districts

\section{STARTING-ZONE LOCATIONS}

The location of slush-flow starting zones is extremely important because of the unique set of requirements for the initiation of flowage. Reports of slush-flow occurrences indicate that prior to release the snow-pack in the starting zone either has a very high water content or is already in a saturated condition due to an excess of water in drainage channels or to the presence of constrictions, obstructions, or depressions where free water can accumulate and/or be retained.

$39 \%$ of respondents indicated that slush-flow starting zones were most frequently located in stream channels (Table IV). In mountainous terrain, these stream channels are of low order with steep-sided slopes, but slush flows also occur in stream channels on broad open flood plains. $31 \%$ of replies suggested that slush flows frequently originate from shallow depressions, whilst another $25 \%$ indicated that the starting zones were located on open slopes. Starting zones where slush flows occur less frequently were also identified by the contributors (Table IV).

\section{TABLE IV. STARTING-ZONE LOCATIONS}

Frequently Infrequently

$39 \%$

$11 \%$

(2) Shallow depressions

$31 \%$

$14 \%$

(3) Open slopes

$25 \%$

(4) Bogs

$1 \%$

(5) Others

$4 \%$

$20 \%$

\section{SLUSH-FLOW TRACKS}

Recipients of the questionnaire were asked to select the characteristic configuration of the slush-flow tracks. The choices offered were as follows: channelled (defined), open slope (undefined), or alternating channelled-undefined. The choices made are shown in Table V. Characteristics of the track are important when a general examination of slush flows is being undertaken. The planimetric geometry of the 
track will be dictated by the configuration of the terrain, and also by the texture and structure of the snow-pack below the starting zone. When considering only those starting-zone locations where slush flows are normally observed, certain similarities become apparent between the characteristics of the starting zone and those of the slush-flow track (Tables IV and V). Slush flows frequently appear in stream channels, open slopes, and shallow depressions. Although shallow depressions rank second in frequency in Table IV, they may be found in both stream channels and on open slopes. The questions which the respondents were asked about starting zones and flow tracks are likely to be inter-related, in that basically they reflect the geomorphic setting within which slush flows occur.

\section{GEOMORPHIC ACTIVITY OF SLUSH FLOWS}

Rapp (1960) indicated that slush flows have the potential for acting as a significant geomorphic agent in Arctic areas. Nyberg (1985) described in detail several erosional and depositional forms produced by slush-flow activity in northern Swedish Lappland, and evidence of slush-flow erosion and deposition is extremely widespread in the Central Brook Range in Alaska (Onesti, 1985). Although literature relating to the consideration of the geomorphic function of slush flows is not very extensive, it is a phenomenon which has been documented.

Responses to the questions about the geomorphic activity of slush flows were fairly uniformly distributed. The respondents indicated that erosion, transportation, and deposition are all part of the geomorphic process associated with slush flows. $30 \%$ indicated that slush flows erode, $38 \%$ that they transport, and $35 \%$ that they deposit (Table VI). The percentage associated with erosion is somewhat lower than the percentage for the other processes but, since transportation and deposition are already taking place, it would naturally follow that erosion would also occur. The term entrainment may possibly be a more suitable one than erosion for use in this context, and in future this may become the appropriate term to use.

\section{SLUSH FLOWS AS HAZARDS}

Slush flows have long been recognized as a serious natural hazard (Rapp, 1966; Jahn, 1967; Hestnes and Sanderson, 1987). The impact of slush flows on human activities is probably less severe than that of snow avalanches, since most reported occurrences have been in relatively remote or isolated areas. However, the questionnaire has revealed that slush flows encroach upon the everyday life of the inhabitants in the same countries as do snow avalanches, and trends in recent decades indicate increasing encroachment of human activity into existing or potential slush-flow zones. Table VII summarizes the numbers of reports that indicated damage, and shows the types of damage which were described.

It is difficult to estimate the indirect economic consequences of slush flows such as loss of life, disruption of road, rail and utility links, construction costs for defending structures, industrial losses due to power output, delays to commercial traffic, and problems of debris removal from transportation routes. The construction of defending structures in slush-flow run-out zones was reported by 16 of the respondents, whilst 38 indicated that no safety devices whatsoever were being used. The types of control method reported are typical of those used in snowavalanche areas; that is to say, methods such as hazard zoning and limitation of access, forecasting warning systems, controlled release of the flow, and the construction of defending structures.

\section{CONCLUSION}

Responses to our questionnaire revealed information with respect to slush-flow activity worldwide which was not previously available to the scientific community. In addition, the questionnaire also indentified respondents who have first-hand experience of slush-flow processes. Slush-flow
TABLE V. SLUSH-FLOW TRACK CHARACTERISTICS

Track

Frequently

Infrequently

(1) Channelled (defined)

$55 \%$

$18 \%$

(2) Open slope (undefined)

$24 \%$

$49 \%$

(3) Alternating channelled-undefined 21\%

TABLE VI. GEOMORPHIC ACTIVITY ASSOCIATED WITH SLUSH FLOWS

Process

Frequently

Inf requently

Erosion

$30 \%$

$32 \%$

Transportation

$35 \%$

$36 \%$

Deposition

TABLE VII. DAMAGE REPORTS

Type

Reports

Man

Buildings

Roads/railways

Hydro-electric power lines/pipelines

Other (heavy equipment/support structures)

occurrence has a much broader geographic distribution than has generally been perceived to be the case. The bulk of the literature on slush flows suggests that the vast majority of significant events take place in the Arctic. In contrast, the use of our questionnaire has demonstrated that slush flows occur in sub-Arctic and mid-latitude regions as well.

The geomorphic setting and meteorological conditions which are associated with slush-flow activity vary according to latitude, altitude, and climatic conditions, all of which are interdependent.

It appears that slush flows can occur both during the spring and during winter months due to the variety of factors or conditions which trigger the flow process. This variety in initiating factors in turn makes slush flows more difficult to predict than snow avalanches.

The purpose of our questionnaire was to summarize, in a qualitative manner, information from individuals and institutes who had first-hand experience with slush-flow activity. There is very little quantitative information available regarding the slush-flow process and hence, from this standpoint, more research and resources must be focused on this topic. Giving due consideration to present and likely future trends, it seems inevitable that human activity will encroach more and more into slush-flow-prone areas, for purpose of recreation, mining, utility and pipeline installation, general construction activity, military maneuvers, and settlement. The probability of death and property damage will correspondingly increase.

\section{ACKNOWLEDGEMENTS}

This research was sponsored and funded by the Norwegian Geotechnical Institute and the Department of Geology, Indiana University, Bloomington, U.S.A., for which help the authors are very grateful. Our appreciation is extended to the International Glaciological Society, the International Snow Science Workshop Committee, and the 
American Association of Avalanche Professionals for the provision of their mailing lists, and to all respondents for their participation in the survey.

\section{REFERENCES}

Clark, M.J. and M. Seppälä. 1988. Slushflows in a subarctic environment, Kilpisjärvi, Finnish Lapland. Arct. Alp. Res., 30(1), 97-105.

Hestnes, E. 1985. A contribution to the prediction of slush avalanches. Ann. Glaciol., 6, 1-4.

Hestnes, E. and F. Sandersen. 1987. Slushflow activity in the Rana district, north Norway. International Association of Hydrological Sciences Publication 162 (Symposium at Davos 1986 - Avalanche Formation, Movement and Effects), 317-330.

Jahn, A. 1967. Some features of mass movement on Spitsbergen slopes. Geogr. Ann., 49A(2-4), 213-225.

Nyberg, R. 1985. Debris flow and slush avalanches in northern Swedish Lappland. Lund Univ. Geogr. Inst. Medd., Avh., 97.
Onesti, L.J. 1985. Meteorological conditions that initiate slushflows in the central Brooks Range, Alaska. Ann. Glaciol., 6, 23-25.

Onesti, L.J. 1987. Slushflow release mechanism: a first approximation. International Association of Hydrological Sciences Publication 162 (Symposium at Davos 1986 - Avalanche Formation, Movement and Effects), 331-336.

Osborn, S. 1852. Stray leaves from an Arctic journal; or eighteen months in the polar regions..., New York, G.P. Putnam.

Rapp, A. 1960. Recent development of mountain slopes in Kärkevagge and surroundings, northern Scandinavia. Geogr. Ann., 42(2-3), 65-200.

Rapp, A. 1966. Solifluction and avalanches in the Scandinavian mountains. Permafrost International Conference, 11-15 November 1963, Lafayette, Indiana. Proceedings. Washington, DC, National Academy of Sciences. National Research Council, 150-154.

Washburn, A.L. and R.P. Goldthwait. 1958. Slushflows. (Abstract.) Geol. Soc. Am. Bull., 69, 1657-1658. 